\title{
Analysis of temporal expression of HTLV-2 reveals similarities and functional differences from HTLV-1
}

\author{
Cecilia Bender ${ }^{1}$, Alessia Cotena ${ }^{1}$, Paola Ronzi ${ }^{2}$, Francesca Rende ${ }^{3}$, llaria Cavallari ${ }^{3}$, Claudio Casoli ${ }^{2}$, \\ Vincenzo Ciminale ${ }^{3}$, Umberto Bertazzoni ${ }^{1^{*}}$ \\ From 15th International Conference on Human Retroviruses: HTLV and Related Viruses \\ Leuven and Gembloux, Belgium. 5-8 June 2011
}

In the present study, we developed a robust splice sitespecific real-time RT-PCR method to quantitate all HTLV-2 transcripts. Results of this analysis conducted on three different infected cell lines (HTLV-2A Mo-T, C344 and HTLV-2B BJAB-Gu) showed that the most abundant mRNA was gag/pol followed by the accessory transcript $1-3$, coding for the $\mathrm{p} 28$ and for $\mathrm{p} 22 / \mathrm{p} 20$ proteins. The third most abundant mRNA was tax/rex.

To investigate if different mRNAs produced by HTLV-2 are expressed at different levels upon viral reactivation, we studied the kinetics of viral expression in PBMCs from three subjects infected with HTLV-2B and cultured in vitro for 48 hours. The level of expression of the full length gag/pol transcript was the highest in all samples. The tax/rex mRNA was detected already at time zero and increased very rapidly following in vitro culture, reaching the highest copy number between zero and 2-4 hours. The minus-strand APH-2 mRNA, was expressed at high level. As observed in the infected cell lines, the 1-3 mRNA was expressed at high levels in all subjects. This finding is particularly intriguing, as it encodes two proteins that were shown to exert a powerful control on Tax and Rex function. This peculiar pattern of expression, which is in striking contrast with that of HTLV-1, might in part explain the differential pathogenicity of the two viruses.

\section{Author details}

'Department of Life and Reproduction Sciences, Section of Biology and Genetics, Università degli Studi di Verona, Verona 37134, Italy. ${ }^{2}$ Department of Clinical Sciences, Università degli Studi di Milano, Milano, Italy.

${ }^{3}$ Department of Oncology, Università degli Studi di Padova, Padova, Italy.

\footnotetext{
* Correspondence: umberto.bertazzoni@univr.it

'Department of Life and Reproduction Sciences, Section of Biology and

Genetics, Università degli Studi di Verona, Verona 37134, Italy

Full list of author information is available at the end of the article
}

Published: 6 June 2011

doi:10.1186/1742-4690-8-S1-A192

Cite this article as: Bender et al.: Analysis of temporal expression of HTLV-2 reveals similarities and functional differences from HTLV-1.

Retrovirology 2011 8(Suppl 1):A192.
Submit your next manuscript to BioMed Central and take full advantage of:

- Convenient online submission

- Thorough peer review

- No space constraints or color figure charges

- Immediate publication on acceptance

- Inclusion in PubMed, CAS, Scopus and Google Scholar

- Research which is freely available for redistribution
() Biomed Central 